\title{
Ethnobotanical Importance and Phytochemical constituents of Parthenium weed (Parthenium hysterophorus L.) - A Review
}

\author{
Sarfaraz Khan Marwat ${ }^{1}$, Fazal-ur-Rehman ${ }^{2}$ and Imdad Ullah Khan ${ }^{3}$
}

\begin{abstract}
Parthenium hysterophorus $\mathrm{L}$. is a harmful weed of family Asteraceae (Compositae). Its chemical constituents and ethnobotanical uses have been reviewed in this paper. The reported phytochemical studies revealed the presence of flavonoids, oils, phenolics, terpenoids, amino acids, alkaloids and others. Different parts of the plant have been reported to be used in traditional medicine against fever, diarrhoea, neurologic disorders, urinary tract infections, dysentery, malaria and as emmenagogue. It is also used as remedy for inflammation, eczema, skin rashes, herpes, rheumatic pain, cold, heart trouble and gynaecological ailments. Although plenty of compounds were isolated from this plant, further work needs to be carried out and explore folk recipes for the benefit of improving human health.
\end{abstract}

Keywords: Parthenium hysterophorus; flavonoids; Asteraceae; biocontrol; Green manure

\section{Introduction}

The genus Parthenium L. of family Asteraceae (Compositae) is distributed in North Central America,

Received: 21 November 2014

Accepted revised version: 2 January 2015

Published online: 8 April 2015

(C) Marwat et al. (2015)

Publisher: Horizon e-Publishing Group

\section{CITATION}

Marwat, S. K., Fazal-ur-Rehman and Khan, I. U. 2015. Ethnobotanical Importance and Phytochemical constituents of Parthenium weed (Parthenium hysterophorus L.) - A Review. Plant Science Today 2(2): 77-81. doi: 10.14719/pst.2015.2.2.113

\section{AUTHOR'S AFFILIATION}

1 Department of Agronomy, Faculty of Agriculture, Gomal University, Dera Ismail Khan, KPK, Pakistan.

2 Faculty of Pharmacy, Gomal University, Dera Ismail Khan, KPK, Pakistan

3 Department of Soil and Environmetal sciences, Faculty of Agriculture, Gomal University, Dera Ismail Khan, KPK, Pakistan.

CORRESPONDENCE

\Sarfaraz Khan Marwat - Email: skhan.marwat@gmail.com
Northern South America and West Indies. It consists of ca.16 species. One species, Parthenium hysterophorus L. is widespread weed. It is the only species, found in Pakistan (Khalid, 2000).

P. hysterophorus $\mathrm{L}$. is commonly known as congress grass, congress weed, carrot grass, dog flea weed, white heads (English), parthenium matricaire (French), ragweed parthenium (USA), chatak chandani, gazar ghas (India), thandhi booti, lewanai bhang (Pakistan) (Parker and Shabbir, 2008 - 2013).

After accidental introduction of Parthenium weed $(P$. hysterophorus L.) in India in the mid-1950s through imported food grains, it has been documented as invasive weed in this continent. Then it has spread over most parts of the neighbouring countries including Pakistan (Javaid and Anjum, 2005). This weed is rapidly spreading in wastelands, degraded areas, rocky crevices, along water channels, roadsides, railway tracks, and also in cultivated lands (Shabbir, 2002) of various parts of Punjab, Khyber Pakhtoon Khawa and Kashmir (Javaid and Anjum, 2005).

$P$. hysterophorus L. has become a major pest plant of the wastelands and metropolitan areas of Islamabad where, many other plants have already been labelled to be the causes of the pollen allergy and hay fever. Heavy infestation of $P$. hysterophorus L., which has also been proved to be an allergy causing plant, poses a serious threat to the inhabitants of the Islamabad (Shabbir and Bajwa, 2007).

The invasive nature of Parthenium weed is due to its ability to form huge monocultural stands with no other plant in the vicinity. That is why it has rapidly substituted local weed flora. Various reports have declared it as noxious weed due to its potential to decrease the crop productivity, fodder scarcity, biodiversity depletion and health problems for livestock and human causing hay fever, skin problems and asthma ( Riaz and Javaid, 2011). 
Table 1. Chemical constituents of Parthenium hysterophorus $\mathrm{L}$.

\begin{tabular}{|c|c|c|c|}
\hline Sl. No. & Compound & Group & Reference(s) \\
\hline 1. & 8-ß-acetoxyhysterone $\mathrm{C}$ & --------------- & Roy and Shaik, 2013 \\
\hline 2. & Acetylated pseudoguaianolides & Pseudoguaianolides & Saini et al., 2014 \\
\hline 3. & $\mathrm{~N}$-acetylgalactosamine & Amino sugars & Roy and Shaik, 2013 \\
\hline 4. & $\mathrm{~N}$-acetylglucosamine & Amino sugars & Roy and Shaik, 2013 \\
\hline 5. & Alanine & Amino acids & Roy and Shaik, 2013; Saini et al., 2014 \\
\hline 6. & Ambrosin & Pseudoguaianolides & Saini et al., 2014 \\
\hline 7. & Anhydroparthenin & Pseudoguaianolides & Saini et al., 2014 \\
\hline 8. & Anisic acid & Phenolics & Parsons and Cuthbertson, 2001; Saini et al.,2014 \\
\hline 9. & Apigenin & Flavonoids & Roy and Shaik, 2013; Saini et al., 2014 \\
\hline 10. & Artecanin & Terpenoids & Roy and Shaik, 2013 \\
\hline 11. & Artemorin & Terpenoids & Roy and Shaik, 2013 \\
\hline 12. & Balchanin & Terpenoids & Roy and Shaik, 2013; Saini et al., 2014 \\
\hline 13. & Borneol & Oils & Roy and Shaik, 2013; Saini et al., 2014 \\
\hline 14. & Bornyl acetate & Oils & Roy and Shaik, 2013; Saini et al., 2014 \\
\hline 15. & Isobornyl 2-methyl butanoate & Oils & Roy and Shaik, 2013; Saini et al., 2014 \\
\hline 16. & Caffeic acid & Phenolics & Parsons and Cuthbertson, 2001; Saini et al.,2014 \\
\hline 17. & Camphene & Oils & Roy and Shaik, 2013; Saini et al.,2014 \\
\hline 18. & Camphor & Oils & Roy and Shaik, 2013; Saini et al., 2014 \\
\hline 19. & Carvacrol & Oils & Roy and Shaik, 2013; Saini et al., 2014 \\
\hline 20. & Caryophyllene & Oils & Roy and Shaik, 2013; Saini et al., 2014 \\
\hline 21. & Caryophyllene oxide & Oils & Roy and Shaik, 2013; Saini et al., 2014 \\
\hline 22. & Centaureidin & Flavonoids & Roy and Shaik, 2013; Saini et al., 2014 \\
\hline 23. & Charminarone & Pseudoguaianolides & Roy and Shaik, 2013; Saini et al., 2014 \\
\hline 24. & Chlorogenic acid & Phenolics & $\begin{array}{l}\text { Parsons and Cuthbertson, 2001; Saini et al., } \\
2014\end{array}$ \\
\hline 25. & Chrysanthemolide & Terpenoids & Roy and Shaik, 2013 \\
\hline 26. & Chrysanthemonin & Terpenoids & Roy and Shaik, 2013 \\
\hline 27. & Chrysanthenone & Oils & Roy and Shaik, 2013; Saini et al., 2014 \\
\hline 28. & Chrysartemin A & Terpenoids & Roy and Shaik, 2013 \\
\hline 29. & Chrysoeriol & Flavonoids & Roy and Shaik, 2013; Saini et al., 2014 \\
\hline 30. & Conchasin A artecanin, & Pseudoguaianolides & Saini et al., 2014 \\
\hline 31. & Cornopolin & Terpenoids & Roy and Shaik, 2013 \\
\hline 32. & Coronopilin & Pseudoguaianolides & Saini et al., 2014 \\
\hline 33. & Costunolide & Terpenoids & Roy and Shaik, 2013; Saini et al., 2014 \\
\hline 34. & p-coumaric acid & Phenolics & Saini et al., 2014 \\
\hline 35. & p-cymene & Oils & Roy and Shaik, 2013; Saini et al., 2014 \\
\hline 36. & p-cymen-8-ol & Oils & Roy and Shaik, 2013; Saini et al., 2014 \\
\hline 37. & Damsin & Pseudoguaianolides & Saini et al., 2014 \\
\hline 38. & Deacetyltetraneurin A & Pseudoguaianolides & Saini et al., 2014 \\
\hline 39. & Epoxyartemorin. & Terpenoids & Roy and Shaik, 2013; Saini et al., 2014 \\
\hline 40. & $8 \alpha$-Epoxymethylacrylyloxyambrosin & ------ & Roy and Shaik, 2013 \\
\hline 41. & $8 \alpha$-Epoxymethylacrylyloxy-11 & ------ & Roy and Shaik, 2013 \\
\hline 42. & $8 \alpha$-Epoxymethylacrylyloxyparthenin & ------- & Roy and Shaik, 2013 \\
\hline 43. & Farnesene & Oils & Roy and Shaik, 2013; Saini et al., 2014 \\
\hline 44. & Ferulic acid & Phenolics & Parsons and Cuthbertson,2001; Saini et al.,2014 \\
\hline 45. & Galactose, & Carbohydrate & Saini et al., 2014 \\
\hline 46. & Germacrene & Oils & Roy and Shaik, 2013; Saini et al., 2014 \\
\hline 47. & Glucose & Carbohydrate & Saini et al., 2014 \\
\hline 48. & Glycine & Amino acids & Roy and Shaik, 2013; Saini et al., 2014 \\
\hline 49. & Humulene & Oils & Roy and Shaik, 2013; Saini et al., 2014 \\
\hline 50. & Hymanin & Pseudoguaianolides & Saini et al., 2014 \\
\hline 51. & Hysterin & Pseudoguaianolides & Saini et al., 2014 \\
\hline 52. & Hysterones A to $\mathrm{E}$ & Pseudoguaianolides & Roy and Shaik, 2013; Saini et al., 2014 \\
\hline 53. & 1-ß-hydroxyarbusculin & Terpenoids & Roy and Shaik, 2013; Saini et al., 2014 \\
\hline 54. & P-hydroxy benzoic acid & Phenolics & Saini et al., 2014 \\
\hline 55. & $2 ß$ and $8 ß$-hydroxycoronopilin & Pseudoguaianolides & Saini et al., 2014 \\
\hline 56. & 8- $\alpha$-hydroxyestafiatin, artecanin & Terpenoids & Roy and Shaik, 2013; Saini et al., 2014 \\
\hline 57. & $2 ß$-Hydroxycoronopilin & --------- & Roy and Shaik, 2013 \\
\hline 58. & 3-ß-hydroxycostunolide & Terpenoids & Roy and Shaik, 2013; Saini et al., 2014 \\
\hline 59. & Dihydroisoparthenin & Pseudoguaianolides & Saini et al., 2014 \\
\hline 60. & Dihydroxyparthenin & Pseudoguaianolides & Saini et al., 2014 \\
\hline 61. & 13-dihydroparthenin & --------- & Roy and Shaik, 2013 \\
\hline 62. & $\begin{array}{l}1 \alpha, 2 ß, 4 ß \text {-Trihydroxypseudoguaian-6ß, } \\
12 \text {-olide }\end{array}$ & --------- & Roy and Shaik, 2013 \\
\hline
\end{tabular}

The major components of toxin being 'Parthenin' and other phenolic acids such as caffeic acid, vanillic acid, anisic acid, chlorogenic acid and parahydroxy benzoic acid are lethal to human beings and animals. In addition to 
Table 1. Chemical constituents of Parthenium hysterophorus L. - Contd.

\begin{tabular}{|c|c|c|c|}
\hline Sl. No. & Compound & Group & Reference(s) \\
\hline 63. & 3-ß-hydroxy- parthenolide & Terpenoids & Roy and Shaik, 2013 \\
\hline 64. & 6-hydroxykaempferol 3,6-dimethyl ether & Flavonoids & Roy and Shaik, 2013; Saini et al., 2014 \\
\hline 65. & $\begin{array}{l}\text { 6-hydroxykaempferol 3,6,4'-trimethyl ether } \\
\text { (tanetin) }\end{array}$ & Flavonoids & Roy and Shaik, 2013; Saini et al., 2014 \\
\hline 66. & 11-H,13-hydroxyparthenin & Pseudoguaianolides & Saini et al., 2014 \\
\hline 67. & 5-ß-hydroxyreynosin & Terpenoids & Roy and Shaik, 2013; Saini et al., 2014 \\
\hline 68. & Jaceidin & Flavonoids & Roy and Shaik, 2013; Saini et al., 2014 \\
\hline 69. & Kaempferol glucoside & Flavonoids & Saini et al., 2014 \\
\hline 70. & Kaempferol glucoarabinoside & Flavonoids & Saini et al., 2014 \\
\hline 71. & $\mathrm{KCl}$ & Salt & Saini et al., 2014 \\
\hline 72. & Lignan & Flavonoids & Saini et al., 2014 \\
\hline 73. & Limonene & Oils & Roy and Shaik, 2013; Saini et al., 2014 \\
\hline 74. & Linalool & Oils & Roy and Shaik, 2013; Saini et al., 2014 \\
\hline 75. & Luteolin & Flavonoids & Roy and Shaik, 2013; Saini et al., 2014 \\
\hline 76. & Lysine & Amino acids & Roy and Shaik, 2013; Saini et al., 2014 \\
\hline 77. & Magnolialide & Terpenoids & Roy and Shaik, 2013 \\
\hline 78. & Melatonin & ---------- & Roy and Shaik, 2013 \\
\hline 79. & 13-methoxydihydroambrosin & Pseudoguaianolides & Saini et al., 2014 \\
\hline 80. & 13-methoxydihydroparthenin & Pseudoguaianolides & Saini et al., 2014 \\
\hline 81. & $2 ß, 13 \alpha$-dimethoxydihydroparthenin & Pseudoguaianolides & Saini et al., 2014 \\
\hline 82. & Myrtenal & Oils & Roy and Shaik, 2013; Saini et al., 2014 \\
\hline 83. & Neochlorogenic acid & Phenolics & Roy and Shaik, 2013; Saini et al., 2014 \\
\hline 84. & Ocimene & Oils & Roy and Shaik, 2013; Saini et al., 2014 \\
\hline 85. & Parthenin & Terpenoids & Roy and Shaik, 2013 \\
\hline 86. & Parthenolide & Terpenoids & Roy and Shaik, 2013 \\
\hline 87. & Partholide & Terpenoids & Roy and Shaik, 2013 \\
\hline 88. & ß-ocimene & Oils & Roy and Shaik, 2013; Saini et al., 2014 \\
\hline 89. & $\alpha$-phellandrene & Oils & Roy and Shaik, 2013; Saini et al., 2014 \\
\hline 90. & $\alpha$-pinene & Oils & Roy and Shaik, 2013; Saini et al., 2014 \\
\hline 91. & Pinocarvone & Oils & Roy and Shaik, 2013; Saini et al., 2014 \\
\hline 92. & Potassium chloride & ------ & Roy and Shaik, 2013 \\
\hline 93. & $ß$-terpene & Oils & Roy and Shaik, 2013; Saini et al., 2014 \\
\hline 94. & Proline & Amino acids & Roy and Shaik, 2013; Saini et al., 2014 \\
\hline 95. & Protein & -------- & Roy and Shaik, 2013 \\
\hline 96. & Protocatechuic acid & Phenolics & Saini et al., 2014 \\
\hline 97. & Pyrethrin & -------- & Roy and Shaik, 2013 \\
\hline 98. & Quercetagetin 3,6-dimethyl ether & Flavonoids & Roy and Shaik, 2013; Saini et al., 2014 \\
\hline 99. & $\begin{array}{l}\text { Quercetagetin 3,6,3'-trimethyl ether (along } \\
\text { with isomeric 3,6,4'-trimethyl ether) }\end{array}$ & Flavonoids & Roy and Shaik, 2013 \\
\hline 100. & Quercetin & Flavonoids & Roy and Shaik, 2013 \\
\hline 101. & Quercetin glucoside & Flavonoids & Saini et al., 2014 \\
\hline 102. & Reynosin & Terpenoids & Roy and Shaik, 2013 \\
\hline 103. & Sabinene & Oils & Roy and Shaik, 2013; Saini et al., 2014 \\
\hline 104. & Santin & Flavonoids & Roy and Shaik, 2013; Saini et al., 2014 \\
\hline 105. & Santamarin & Terpenoids & Roy and Shaik, 2013 \\
\hline 106. & Saponins & along with Flavonoids & Saini et al., 2014 \\
\hline 107. & Scopoletin & Pseudoguaianolides & Saini et al., 2014 \\
\hline 108. & Syringaresinol & Flavonoids & Saini et al., 2014 \\
\hline 109. & $ß$-myrcene & Oils & Roy and Shaik, 2013; Saini et al., 2014 \\
\hline 110. & Tannins (type unspecified) & ------- & Roy and Shaik, 2013 \\
\hline 111. & ß-terpene & Oils & Roy and Shaik, 2013; Saini et al., 2014 \\
\hline 112. & Tetraneurin-A & Pseudoguaianolides & Saini et al., 2014 \\
\hline 113. & Tetraneurin-E & Pseudoguaianolides & Saini et al., 2014 \\
\hline 114. & $\alpha$-terpinene & Oils & Roy and Shaik, 2013; Saini et al., 2014 \\
\hline 115. & $\gamma$-terpinene & Oils & Roy and Shaik, 2013; Saini et al., 2014 \\
\hline 116. & $\alpha$-terpineol & Oils & Roy and Shaik,2013,Saini et al., 2014 \\
\hline 117. & Terpinene-4-ol & Oils & Roy and Shaik, 2013; Saini et al., 2014 \\
\hline 118. & $\alpha$-thujene & Oils & Roy and Shaik, 2013; Saini et al., 2014 \\
\hline 119. & Trans-myrtenol acetate & Oils & Roy and Shaik, 2013; Saini et al., 2014 \\
\hline 120. & Tricylene & Oils & Roy and Shaik, 2013; Saini et al., 2014 \\
\hline 121. & Vanillic acid & Phenolics & Parsons and Cuthbertson, 2001; Saini et al., 2014 \\
\hline 122. & Ugenol & Oils & Roy and Shaik, 2013; Saini et al., 2014 \\
\hline 123. & $\alpha$-unsaturated $\gamma$-lactones & Terpenoids & Roy and Shaik, 2013 \\
\hline
\end{tabular}

health hazards lot of available data also highlights its and Anjum, 2005). Although plenty of compounds were impact on agriculture as well as natural ecosystems (Javaid isolated from this plant (Table 1), further work needs to be 
carried out and explore folk recipes for the benefit of improving human health.

\section{Taxonomy and Nomenclature}

$\begin{array}{ll}\text { Domain: } & \text { Eukaryota } \\ \text { Kingdom: } & \text { Plantae } \\ \text { Phylum: } & \text { Spermatophyta } \\ \text { Subphylum: } & \text { Angiospermae } \\ \text { Class: } & \text { Dicotyledonae } \\ \text { Order: } & \text { Asterales } \\ \text { Family: } & \text { Asteraceae } \\ \text { Genus: } & \text { Parthenium } \\ \text { Species: } & \text { hysterophorus L. (Anonymous, 2014). }\end{array}$

\section{Description}

Parthenium hysterophorus L. is an annual herb with a deep tap root and an erect stem that becomes woody with age. As it matures, the plant develops many branches in its top half and may eventually reach height of two metres. Leaves are pale green, deeply lobed and covered with fine soft hairs. Flowers small creamy white lowers occur on the tips of the numerous stems. Each flower develops 4-5 black seeds that are wedge-shaped, two mm long with two thin, white scales (DEEDI, 2011).

Parthenium weed normally germinates in spring and early summer, produces flowers and seeds throughout its life and dies around late autumn. However, with suitable conditions (rain, available moisture, mild temperatures), it can grow and produce flowers at any time of the year. In summer, plants can flower and set seed within four weeks of germination, particularly if stressed (DEEDI, 2011). An individual plant may produce $15,000-25,000$ seeds (Javaid and Anjum, 2005).

\section{Habitat}

P. hysterophorus L. occurs in humid and subhumid tropics, typically favouring heavier fertile soils, such as black, alkaline clay loams, but is able to grow on a wide variety of soil types from sea level up to $2400 \mathrm{~m}$. Areas receiving less than $500 \mathrm{~mm}$ of rainfall annually are probably unsuitable, although the weed has strong adaptive methods to tolerate both moisture stress and saline conditions (Parker and Shabbir, 2008-2013).

\section{Uses}

The decoction of $P$. hysterophorus $\mathrm{L}$. has been used in traditional medicine to treat fever, diarrhoea, neurologic disorders, urinary tract infections, dysentery, malaria and as emmenagogue. Ethnobotanically, it is used as remedy for inflammation, eczema, skin rashes, herpes, rheumatic pain, cold, heart trouble and gynaecological ailments. $P$. hysterophorus L. has been found to be pharmacologically active as analgesic in muscular rheumatism, therapeutic for neuralgia and as vermifuge. This weed is also reported as promising remedy against hepatic amoebiasis. Parthenin, the major constituent of the plant, exhibits significant medicinal attributes including anticancer property (Patel, 2011). Decoction of roots is used in dysentery and helpful in skin disorders. Plant used as tonic, febrifuge, emmenagogue and analgesic (Ravinder and Vashistha, 2014). Parthenium weed is used as a herbal remedy for various intestinal and skin disorders using a decoction of boiled roots. It has potential medicinal properties due to antitumor and antiamoebic activities (Anonymous. 2014). The whole plant is bitter and strong-scented, reckoned tonic, stimulating and anti-hysteric. It was once a popular remedy in ague. Its odour is said to be peculiarly disagree to bees and that insects may be easily kept at a distance by carrying a handful of the flower heads (Oudhia, 2014).

The application of parthenium weed compost and green leaf manure was reported to lower weed populations in rice. This was due to the role of allelopathic compounds present in it, an increase in soil moisture due to the build-up of soil organic carbon, increased soil N, P and $\mathrm{K}$ content, and a reduced incidence of pests in rice such as stem borers and leaf rollers. Parthenium weed is also potentially a rich source of potash. Parthenium weed stem is boiled in water and used to remove the toothache and strong the gums. Ground root in water is used to remove boils and pimples. Its leaves extraction is used insomnia by pouring its drops in eyes (Noor and Kalsoom, 2011). It is carminative, leaves juice gives strength to the stomach and relief from constipation. Some people use it in fever also (Mahmood et al., 2011).

\section{Competing interests}

The authors declare that they have no competing interests.

\section{References}

Anonymous. 2014. Parthenium hysterophorus. Invasive Species Compendium http://www.cabi.org/isc/datasheet/45573

DEEDI, 2011. Fact sheet.Declared Class 2 PEST Plant. Parthenium weed Parthenium hysterophorus. The State of Queensland, Department of Employment, Economic Development and Innovation, pp.1- 4. http://www.daff.qld.gov.au/data/assets/pdf_file/0004/68 602/IPA-Parthenium-PP2.pdf

Javaid, A., and T. Anjum. 2005. Parthenium hysterophorus L. - A Noxious alien weed. Pakistan Journal of Weed Science Research 11(3-4): 81 - 87.

Khalid, S. 2000. Parthenium hysterophorus L.Sp.Pl.: 988 (1753). A New Introduction to Pakistan. Pakistan Journal of Biological Sciences 3(5): 846-847. doi: 10.3923/pjbs.2000.846.847

Mahmood, A., R. A. Qureshi, A. Mahmood, Y. Sangi, H. Shaheen, I. Ahmad and Z. Nawaz. 2011. Ethnobotanical survey of common medicinal plants used by people of district Mir pur AJK, Pakistan. Journal of medicinal Plant Research 5(18): 4493-4498. 
Noor, M. J., and U. Kalsoom. 2011. Ethnobotanical studies of selected plant species of Ratwal Village, District Attock, Pakistan .Pak. J. Bot. 43(2): 781-786.

Oudhia, P. 2014. Parthenium hysterophorus: Traditional Medicinal Uses India. www.celestine-india.com/pankajoudhia

Parker, C., and A. Shabbir, A. 2008 - 2013. Invasive Species Compendium, Parthenium hysterophorus L. http://www.cabi.org/isc/datasheet/45573

Parsons ,W. T., and E. G. Cuthbertson. 2001. Noxious Weeds of Australia. CSIRO Publishing.

Patel, S. 2011. Harmful and beneficial aspects of Parthenium hysterophorus: an update. 3 Biotech 1(1): 1-9. doi: 10.1007/s13205-011-0007-7

Ravinder, K., and B. D. Vashistha. 2014. Ethnobotanical Studies on Karnal District, Haryana, India. International Research Journal of Biological Sciences 3(8): 46-55.

Riaz, T., and A. Javaid. 2011. Prevalence of alien weed Parthenium hysterophorus L. in grazing and wastelands of District attock, Pakistan. The Journal of Animal and Plant Sciences 21(3): 542-545

Roy, D. C., and Shaik, M.M. (2013). Toxicology, Phytochemistry, Bioactive compounds and Pharmacology of Parthenium hysterophorus, Journal of Medicinal Plants Studies, 1(3):126-141.

Saini,A., N. K. Aggarwal, A. Sharma, M. Kaur and A. Yadav. 2014. Utility Potential of Parthenium hysterophorus for its Strategic Management, Advances in Agriculture, vol. 2014, Article ID 381859, 16 pages. doi:10.1155/2014/381859

Shabbir, A. 2002. Parthenium hysterophorus L; An exotic weed threatening the biodiversity and agricultural lands of Islamabad and adjoining districts. M. Phil thesis Department of Botany, University of the Punjab, Lahore, Pakistan.

Shabbir, A., and R. Bajwa. 2007. Parthenium invasion in Pakistan - A Threat still unrecognized. Pakistan Journal of Botany 39(7): 2519-2526. 